\title{
Diurnal Wind Variation in the Troposphere and Lower Stratosphere over Japan
}

\author{
By Atsushi Yoshida* and Isamu Hirota \\ Geophysical Institute, Kyoto University \\ (Manuscript received 5 August 1978, in revised form 6 January 1979)
}

\begin{abstract}
The diurnal variation of wind at nine levels between 1000 and $100 \mathrm{mb}$ over eight Japanese stations is obtained from the balloon data during the period of 1956 and 1958 . The result of computation indicates that the structure and behavior of the diurnal tidal motion in the troposphere and lower stratosphere are strongly affected by surface topography.

This fact is also confirmed by a comparison study of vertical distributions of the diurnal meridional wind oscillation at a coastal, an inland and a mid-ocean stations in middle latitudes. The dominance of vertically propagating modes in the lower atmosphere over the coastal station, and somewhat large magnitude of trapped modes originated in the planetary boundary layer over the inland station are found.

Difference between the observation and theory is also discussed.
\end{abstract}

\section{Introduction}

Daily variations of the wind, pressure and temperature in the upper atmosphere have been investigated by many authors for many stations, to present the detailed pictures of the vertical structure of diurnal and semidiurnal tidal motions below $30 \mathrm{~km}$ (Johnson, 1955: Harris, 1959: Harris et al., 1962, 1966: Carlson and Hastenrath, 1970).

In their study of the summer daily wind oscillation over the central United States, Hering and Borden (1962) found that the instantaneous wind vectors at the peak amplitude levels $(1,5$ and $12 \mathrm{~km}$ ) appear to be associated with surface topography. Wallace and Hartranft (1969) and Wallace and Tadd (1974) extensively investigated the topographic influence using 12-hourly wind difference vectors. Wallace and Tadd reported that the topography influences the diurnal wind oscillation up to at least $28 \mathrm{~km}$.

However, a detailed quantitative study of the planetary-scale structure of the upper-air tidal motion has not been made yet, for lack of adequate number of determinations of the diurnal wind oscillation.

\footnotetext{
* Present affiliation: School of Meteorology, University of Oklahoma, U.S.A.
}

On the other hand, the theory of the diurnal tide excited by the heating due to the stratospheric and mesospheric ozone and the tropospheric water vapor was obtained by Lindzen (1966) and Kato (1966). Lindzen's theory is generally in good agreement with observations between 30 and $60 \mathrm{~km}$ for latitudes from $8^{\circ} \mathrm{S}$ to $64^{\circ} \mathrm{N}$ (Reed et al., 1969). However, the theory is inadequate to explain the structure and behavior of the observed diurnal tidal motion in the lowest $30 \mathrm{~km}$ of the atmosphere. Observed features of the seasonal variation of the diurnal tide, such as almost a complete reversal of phase between summer and winter at $30 \mathrm{mb}$ level (Wallace and Tadd), cannot be explained by the theory, either. Wallace and Tadd suggested the effects of the mean wind field, the forcing due to land-sea distribution and irregularities in terrain height, as the possible causes of discrepancy between the observation and the theory.

Therefore, further quantitative studies of the diurnal tide in the lower atmosphere for more stations distributed over the globe are desired in order to be compared with the results of theoretical studies. In this regard, the purpose of the present study is to report the observed diurnal wind variation over Japan and the overall picture of its vertical and seasonal dependence. 
A comparison with results for a few other hour. locations is also made to find some discrepancy between the observation and the theory.

\section{Data and computational procedures}

The data used in the present study mainly consist of the monthly-mean values of the observed wind speed and direction for each of six times daily (0300 and 1500 GMT in $1956 * / 0000$, 0600,1200 and 1800 GMT in 1958). Nine levels from 1000 to $100 \mathrm{mb}$ are chosen for this analysis at eight stations located between $33^{\circ} \mathrm{N}$ and $46^{\circ} \mathrm{N}$ (see Table 1).

Table 1. List of stations used

\begin{tabular}{lccc} 
& Latitude, & Longitude, & Elevation, \\
& $N$ & $E$ & \multicolumn{1}{c}{$m$} \\
\hline Shionomisaki & $33^{\circ} 27^{\prime}$ & $135^{\circ} 46^{\prime}$ & 69.0 \\
Yonago & 3526 & 13321 & 7.9 \\
Tateno & 3603 & 14008 & 27.2 \\
Wajima & 3723 & 13654 & 6.9 \\
Sendai & 3816 & 14054 & 39.8 \\
Akita & 3943 & 14006 & 9.9 \\
Sapporo & 4303 & 14120 & 18.1 \\
Wakkanai & 4525 & 14141 & 3.2 \\
\hline
\end{tabular}

These data are taken from the data books, Geophysical Review and Aerological Data of Japan, both of which have been published monthly by Japan Meteorological Agency.

The method of computation used here is based on that reviewed by Chapman and Lindzen $(1970$, p. 63). Assuming that the wind in the upper air consists of a prevailing, a diurnal and a semidiurnal wind components only, i.e.,

$$
\begin{aligned}
& {\left[\begin{array}{l}
U \\
V
\end{array}\right]=\left[\begin{array}{l}
u_{0}+\Delta u_{0} \\
v_{0}+\Delta v_{0}
\end{array}\right]+\left[\begin{array}{l}
u_{1} \cos \left(15 t-\sigma_{u_{1}}\right) \\
v_{1} \cos \left(15 t-\sigma_{v_{1}}\right)
\end{array}\right]} \\
& +\left[\begin{array}{l}
u_{2} \cos \left(30 t-\sigma_{u_{2}}\right) \\
v_{2} \cos \left(30 t-\sigma_{v_{2}}\right)
\end{array}\right]
\end{aligned}
$$

a harmonic analysis is carried out for each of $U$ (southward wind component) and $V$ (eastward wind component) sequences for each month. Here, $u_{0}$ and $v_{0}$ are prevailing winds of the $U$ and $V$ components respectively and $t$ is a local time. Secular variations $\Delta u_{0}$ and $\Delta v_{0}$ are taken into account. Following Carlson and Hastenrath (1970), we used in Eq. (1) cosine functions instead of sine functions. In this case, the resulting phase $\sigma_{u_{1}}\left(\sigma_{v_{1}}\right)$ indicates an hour angle at which a maximum diurnal wind of $u_{1}\left(v_{1}\right)$ occurs, so that $\sigma / 15^{\circ}$ corresponds to its local time in

* The 6-hourly Rawin observation was not routinely made at most Japanese stations prior to July 1957.

The semidiurnal component, however, cannot be derived by a least-square method from our time series of observations for lack of time resolution. Hence we will hereafter denote the diurnal oscillations of the southward and eastward wind components, i.e., the first harmonics in Eq. (1), as $u$ and $v$ respectively for convenience.

Annual mean (and seasonal mean) amplitude and phase of the diurnal component are calculated from the monthly values of the first harmonics in Eq. (1). We adopt the following definition of seasons;

\begin{tabular}{cll} 
Symbols & Name & \multicolumn{1}{c}{ Months included } \\
$J$ & summer & May to August \\
$E$ & equinox & $\begin{array}{l}\text { March, April, Sep- } \\
\text { tember, October }\end{array}$ \\
& & November to February \\
$D$ & winter & all twelve
\end{tabular}

The radius of the probable-error circle of the annual mean of twelve monthly values [hereafter, for brevity, reffered to as the probable error or P.E.] is calculated to show the reliability of the results.

Moreover, for the purpose of estimating the reliability of the monthly-mean wind speed and direction listed in the data book, an attempt is also made to obtain differently the monthly mean value with higher accuracy, based on the daily data at Tateno in the same period (1956 and 1958) taken from Aerological Data of Japan. The levels of altitude chosen for this calculation are every $2 \mathrm{~km}$ between 2 and $20 \mathrm{~km}$.

\section{Results}

Before presenting the result of computation in detail, we compare the reliability between the two sets of data at Tateno; one is based on the monthly-mean values as original data, and the other the daily values. Shown in Fig. 1 are the amplitudes of $u$ and $v$ together with the probable errors; circles denote the results derived from the latter data, while crosses do those derived from the former. No significant difference is found between the two, since magnitudes of their probable errors are nearly equal. This result assures that the analysis for other stations would have the same reliability as those calculated from the daily values.

The results of the harmonic analysis for the annual mean values at individual stations are illustrated in Fig. 2, and are tabulated in Ap- 


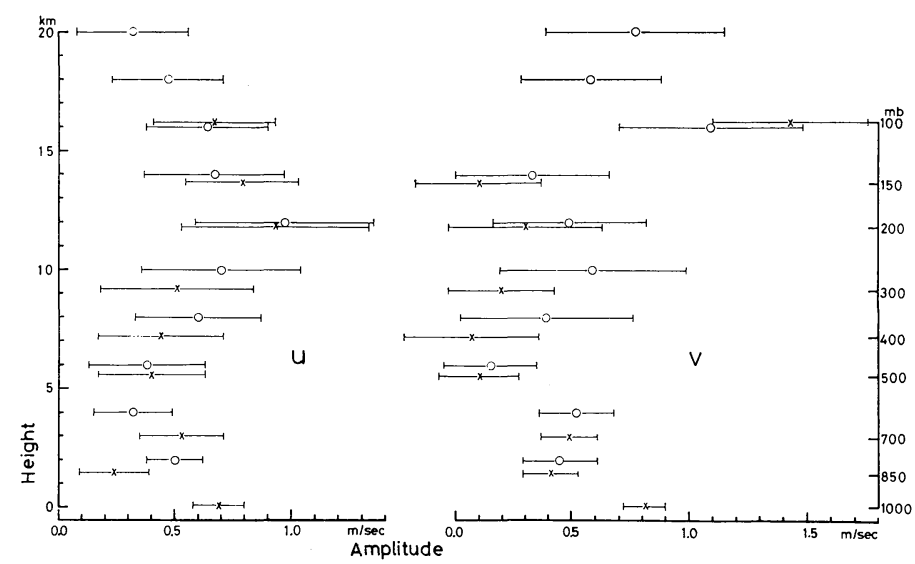

Fig. 1 Amplitudes of the diurnal variation of southward wind component $u$ and eastward wind component $v$ for the annual mean in 1956 and 1958 over Tateno, together with the probable error bars. Circles are determined based on the daily data of wind direction and speed; crosses are based on the monthly mean data.

pendix. The results for other seasons $(J, E, D)$ are not reproduced here.

As a representative of those of the eight stations, let us examine the Tateno's vertical distribution of amplitude and phase in detail. For the $u$ component, the amplitude has three maxima at 3,8 and $12 \mathrm{~km}$ with magnitude of the orders of $0.5,0.6$ and $1.0 \mathrm{~m} / \mathrm{sec}$ respectively. The phase angle above the planetary boundary layer increases with altitude up to about $10 \mathrm{~km}$, and remains constant (about $15^{\circ}$ or 0100 LT) or decreases slowly at higher altitude. Results for other stations also show the similar features of distribution (see Fig. 2(a)), though the maximum of amplitude at $3 \mathrm{~km}(700 \mathrm{mb})$ at Tateno is found at lower level (about $2-0 \mathrm{~km}$ or 850 $1000 \mathrm{mb}$ ) and the second maximum at $8 \mathrm{~km}$ is at 5 or $9 \mathrm{~km}(900$ or $300 \mathrm{mb})$ for most stations. From these results it seems to suggest that the maximum amplitude at $5 \mathrm{~km}$ found by Hering and Borden (1962) over the central United States depends on local topography.

For $v$, the maxima of amplitude are observed at 4,10 and $16 \mathrm{~km}$ over Tateno, with magnitude of about $0.5,0.6$ and $1.4 \mathrm{~m} / \mathrm{sec}$ respectively. These levels differ in altitude with a range of about $\pm 2 \mathrm{~km}$ depending on locations (Fig. 2(b)). The phase progresses upward up to the highest altitude of the present analysis $(100 \mathrm{mb})$ at most stations, though it behaves somewhat differently from station to station. Topographic influence on the diurnal tidal in topography. motion is seen more clearly in Fig. 3, where the harmonic dial vectors are plotted on the maps of $1000,500,200$ and $100 \mathrm{mb}$ levels for $u$ (Fig. 3(a)) and $v$ (Fig. 3(b)) respectively. The values at Osan, Korea are taken from the paper of Harris et al. (1966).

Eight Japanese stations may be classified into two groups, depending on which side of the east and the west of the Japanese Islands the station is located in. Shionomisaki, Tateno and Sendai are of the first group, the east coast stations; on the other hand, Yonago, Wajima, Akita, Sapporo and Wakkanai are of the second group, the west coast stations.

The diurnal variation at $1000 \mathrm{mb}$ mainly consists of a land-sea breeze, since the harmonic dial vectors of the two groups point to almost the opposite directions each other. As for $u$, the effect of differential heating due to the land-sea distribution seems to become weak at $500 \mathrm{mb}$, since there is no large systematic difference in phase distributions between the two groups at this level. Some other small influence, however, still remains at higher levels as noted by Wallace and Tadd (1974).

Compared with $u$, the $v$ component appears to be influenced much more by local condition, and it is difficult to find a systematic feature of $v$ at higher levels. This irregularity may be partly due to the influence of the spatial inhomogeneties in the mean flow, in the heating force, and/or 

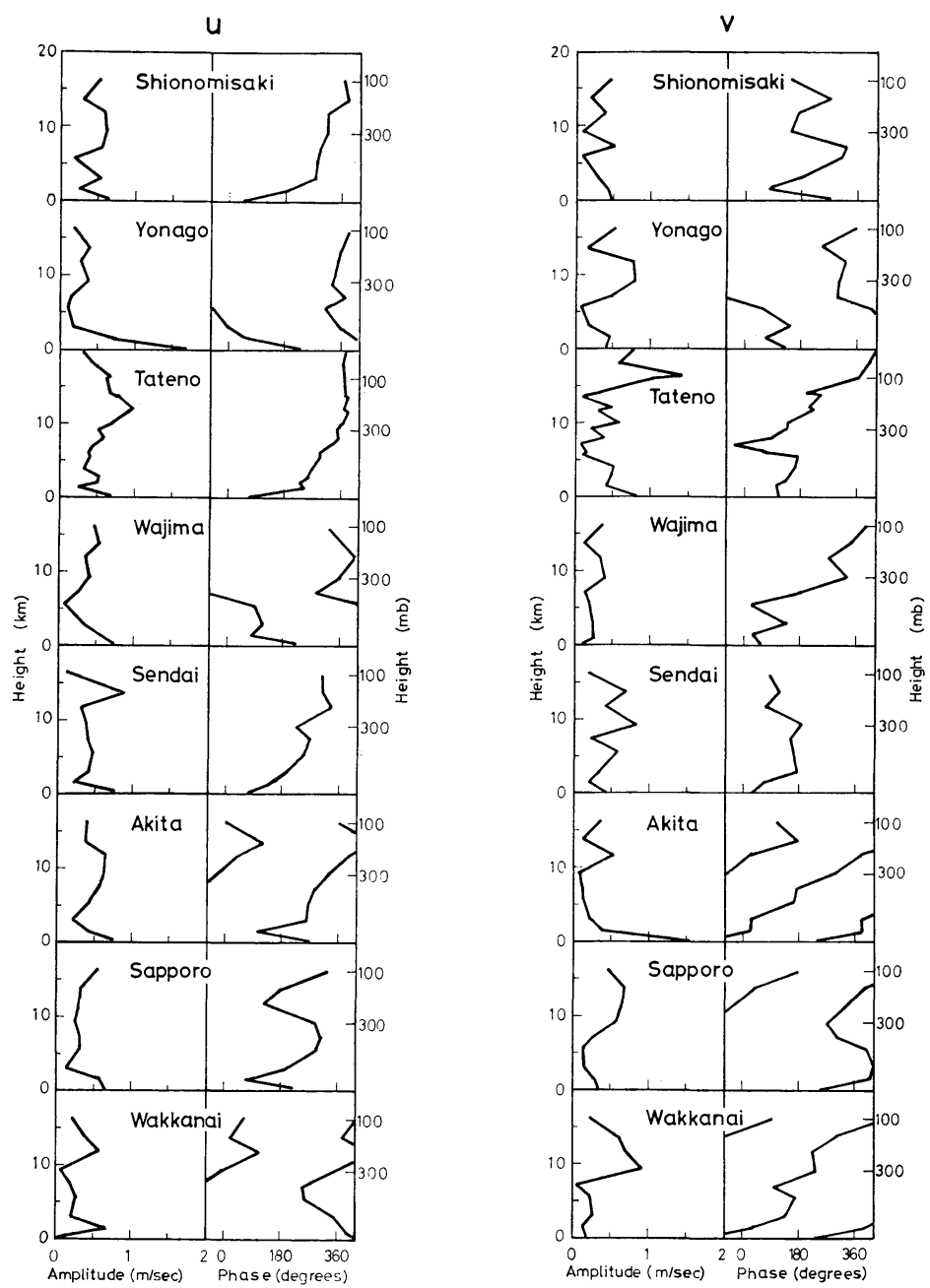

Fig. 2 Amplitudes and phases of the diurnal variations of southward wind component $u$ (a) and eastward wind component $v$ (b) for the annual mean in 1956 and 1958 over 8 Japanese stations.

Finally, to see briefly the seasonal variations result with the earlier ones for other middleof $u$ and $v$, we display the summer (season $J$ ) latitude stations obtained by other authors. In and winter (season $D$ ) means of harmonic dial Fig. 5, we display the annual mean amplitudes vectors for two levels in Fig. 4. There appears and phases for Osan, Korea $\left(37^{\circ} 6^{\prime} \mathrm{N}, 127^{\circ} 2^{\prime} \mathrm{E}\right)$, large seasonal phase variation at some stations, Fort Worth, Texas $\left(32^{\circ} 50^{\prime} \mathrm{N}, 97^{\circ} 3^{\prime} \mathrm{W}, 173 \mathrm{~m}\right)$, e.g., Sendai $(100 \mathrm{mb})$, Wajima and Yonago (500 and Terceira, Azores $\left(38^{\circ} 45^{\prime} \mathrm{N}, 27^{\circ} 5^{\prime} \mathrm{W}, 53 \mathrm{~m}\right)$, $\mathrm{mb}$ ), although no clear relation between the two all obtained by Harris et al. (1966), together with seasons is found. However, it is noteworthy that those for Tateno. Note that Osan is located at an irregular pattern remains at higher altitude in coast as well as Tateno, Fort Worth is at inland winter than in summer. This may be due to the in the Great Plains, and Terceira is at mid-ocean predominance of the strong mean westerly flow of the North Atlantic; the last two stations are in wintertime.

\section{Comparison with other stations' results and the theory}

It is of quite interest to compare the present zonal component $v$ (Fig. 1). 



Fig. 3 Harmonic dial vectors of the diurnal variations of southward wind component $u$ (a) and eastward wind component $v$ (b) for the annual mean in 1956 and 1958 for the 100-, 200-, 500- and 1000-mb levels. Directions of vectors measured clockwise from the downward direction denote the phase angles (or the local hours of maximum), 0-360 degrees (or 0000$2400 \mathrm{LT})$. Lengths of them show the amplitudes on the scale shown by the inset in the top map. Vectors are centered on the stations. Values at Osan, Korea are taken from Harris et al. (1966).

The amplitude and phase of the diurnal tide in an isothermal atmosphere $\left(T=260^{\circ} \mathrm{K}\right)$ for equinoctial condition is also illustrated in the figure, which is reproduced following Lindzen $(1966,1967)$. We assume here that the equinoctial condition can be regarded as the representative of the annual mean condition with good reliability.

At Osan, the phase progresses rapidly with altitude from the surface up to $3 \mathrm{~km}$, and its value is nearly constant between 3 and $7 \mathrm{~km}$. It changes abruptly about 150 degrees (10 hours) between 8 and $10 \mathrm{~km}$, and is again constant (about $30^{\circ}$ or 0200 LT) above this level. Osan's phase distribution resembles those at Tateno (Fig. 5), Shionomisaki, Sendai and Akita (Fig. 2(a)), except for the levels between 5 and $8 \mathrm{~km}$. Contrary to these observations, the result from Lindzen's theory shows a downward progression of phase in the atmosphere below $20 \mathrm{~km}$. We can say, therefore, that the upward propagating modes originated in the planetary boundary layer are relatively strong in the troposphere over the coastal station in middle latitude, while in the 

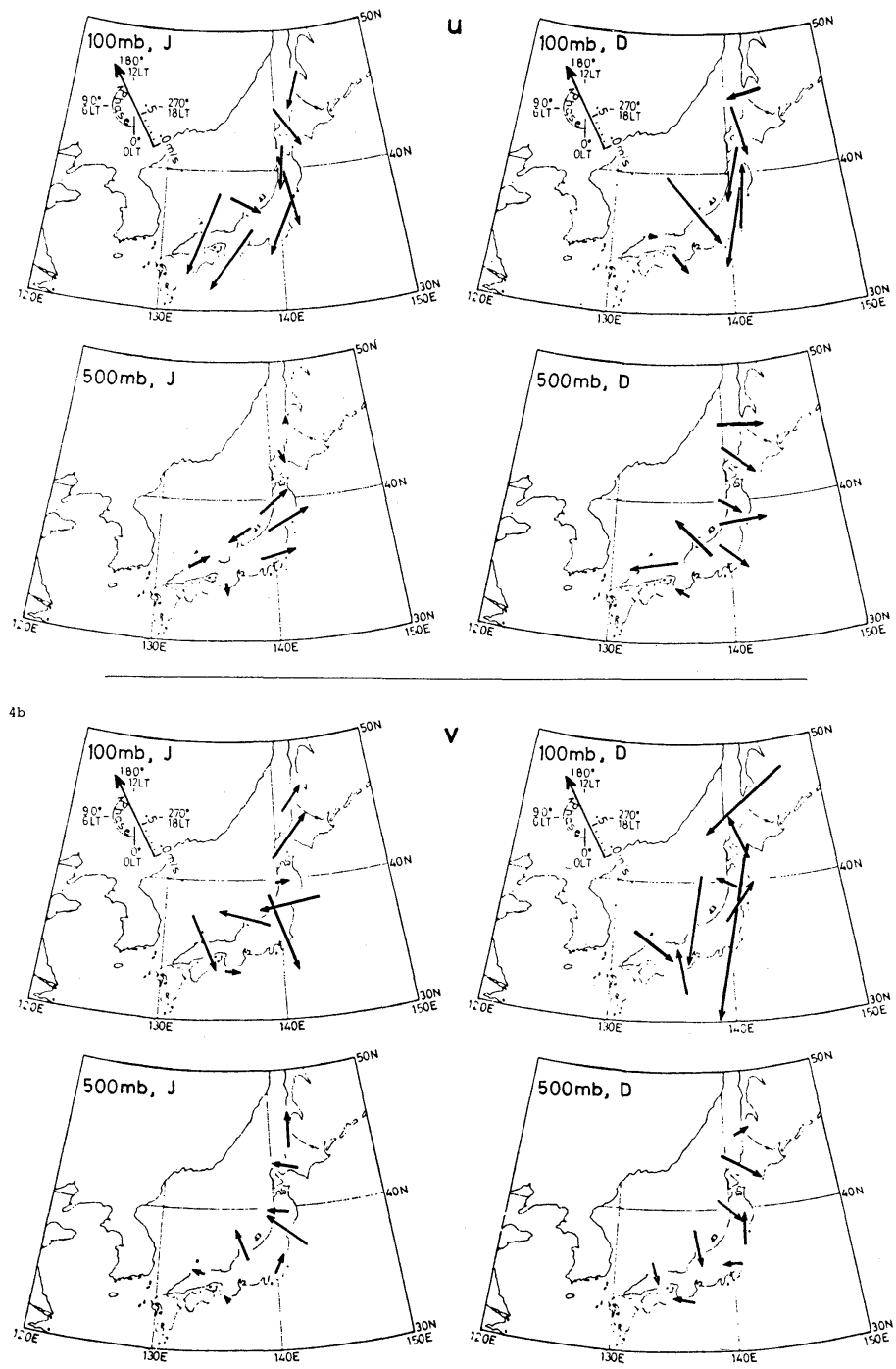

Fig. 4 Same as Fig. 3 but for the summer $(J)$ and the winter $(D)$ in 1956 and 1958 for the $100-$ and $500-\mathrm{mb}$ levels.

lower stratosphere they will have amplitudes comparable to the downward propagating modes excited in the stratosphere.

The amplitude distribution for Osan below $20 \mathrm{~km}$ shows a similar character to that of Tateno in that it oscillates with height in the troposphere, though the magnitude of the former is several times smaller.

At Fort Worth, the phase fluctuates with altitude with the largest deviation of about four hours (60 degrees) from 0000 LT. More notable features, which are not found at any other stations, in the vertical distribution of $u$ are the appearance of the maximum amplitude $(0.89 \mathrm{~m} /$ sec) at $5 \mathrm{~km}$ and the gradual decrease in amplitude with altitude with small fluctuation. These are suggestive of rather great magnitudes of the trapped modes at inland-type stations.

On the other hand, Terceira shows a vertical distribution of amplitude different from those at other stations. The amplitude increases slowly upward and its magnitude is slightly less above the tropopause than that predicted by the theory. Above this level the phase regresses upward very gradually; however it regresses downward below this level contrary to the downward phase progression predicted by the theory. Since the midocean station is considered not to be much in- 


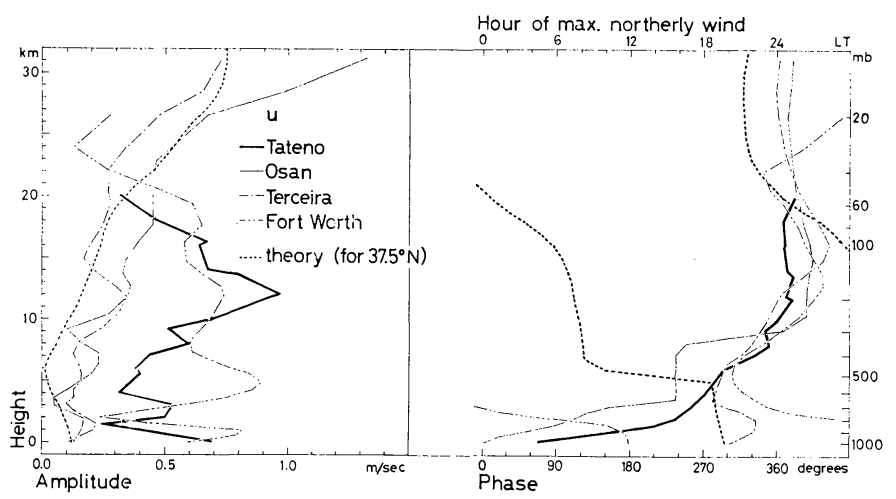

Fig. 5 Amplitudes and phases of the diurnal variations of southward wind component $u$ for the annual mean in 1956 and 1958 at Tateno; Osan, Korea; Terceira, Azores; Fort Worth, Texas. The values for stations except Tateno are taken from Harris et al. (1966). Dashed lines are those for the latitude of $37.5^{\circ} \mathrm{N}$ for an isothermal atmosphere $\left(T=260^{\circ} \mathrm{K}\right)$ of the equinoctial condition, which is calculated based on Lindzen's $(1966,1967)$ theory.

fluenced by local condition such as topography, we believe that the most portion of the deviation at Terceira from the theoretical prediction is probably due to the causes independent of the station type.

From the discussion above we can conclude that, at middle latitudes, the upward propagating modes originated in the planetary boundary layer are dominant at the coastal station, while somewhat great magnitudes of the trapped modes probably excited by the surface temperature variation or by the terrain height can be observed at the inland station. Delay in phase from the theory in the stratospheric level over all stations will be modified partly by considering the basic flow in the stratosphere. Some of the discrepancy between the observation and the theory in the troposphere are also probably due to the effects of the mean wind, the horizontal temperature gradient and the convection in this layer.

\section{Conclusions}

The observational study presented here has shown an overall picture of the vertical structure of the diurnal wind variation at several Japanese stations. The result shows that the altitude of the maximum amplitude found by Hering and Borden (1962) varies depending on local topographic conditions.

The maps of harmonic dial vectors in the Far East region exhibit the spatial variation of the diurnal tidal motion at each level. They confirm more quantitatively the conclusions of Wallace and Hartranft (1969) and Wallace and Tadd (1974) for the local topographic influence on the tidal field up to the high level. It is also indicated that the local irregularity of the tidal motion in middle latitudes is notable at higher altitude in winter than in summer.

The comparison study of the vertical distributions of $u$ at the three different types of locations in middle latitudes clearly shows the influence of land-sea distribution. Furthermore, the comparison between the inland station and the midocean station suggests the influence of the surface on the diurnal tidal motion in the upper atmosphere, such as by the daily variation of the surface temperature or the terrain height, as pointed out by Wallace and Tadd, and others. This is in contrast to Siebert's (1961) conclusion that the atmospheric response to the surface temperature variation is very small.

More extensive and reliable presentation of the harmonic dial vectors for upper-air tidal motions will give us full information concerning the planetary-scale feature of the topographically induced tidal waves and other non-migrating waves with higher wavenumbers.

\section{Acknowledgements}

The authors wish to thank Professor R. Yamamoto for his encouragement throughout the work. Thanks are also due to Mrs. S. Fukuyama for typing the manuscript.

The computation was performed with the aid of the FACOM M-190 computer at Kyoto University. 


\section{Appendix}

The annual means of amplitude (AMP), phase (PHA), and probable error (PE) of the observed diurnal wind variations at eight Japanese stations, for the period of 1956 and 1958. Amplitude and probable error: $\mathrm{m} / \mathrm{sec}$. phase: degrees.

(a) Southward wind component $(u)$

\begin{tabular}{|c|c|c|c|c|c|c|c|c|c|c|c|c|}
\hline \multirow[b]{2}{*}{ Height } & \multicolumn{3}{|c|}{ Shionomisaki } & \multicolumn{3}{|c|}{ Yonago } & \multicolumn{3}{|c|}{ Tateno } & \multicolumn{3}{|c|}{ Wajima } \\
\hline & AMP & PHA & PE & AMP & PHA & PE & AMP & PHA & PE & AMP & PHA & PE \\
\hline $1000 \mathrm{mb}$ & 0.65 & 43 & 0.10 & 1.66 & 231 & 0.14 & 0.69 & 69 & 0.11 & 0.74 & 217 & 0.17 \\
\hline $850 \mathrm{mb}$ & 0.25 & 193 & 0.15 & 0.70 & 55 & 0.16 & 0.24 & 242 & 0.15 & 0.54 & 75 & 0.17 \\
\hline $2 \mathrm{~km}$ & & & & & & & 0.50 & 236 & 0.12 & & & \\
\hline $700 \mathrm{mb}$ & 0.54 & 276 & 0.17 & 0.17 & 1 & 0.18 & 0.53 & 255 & 0.18 & 0.34 & 109 & 0.17 \\
\hline $4 \mathrm{~km}$ & & & & & & & 0.32 & 272 & 0.17 & & & \\
\hline $500 \mathrm{mb}$ & 0.18 & 282 & 0.21 & 0.11 & 304 & 0.22 & 0.40 & 291 & 0.23 & 0.08 & 91 & 0.26 \\
\hline $6 \mathrm{~km}$ & & & & & & & 0.38 & 294 & 0.25 & & & \\
\hline $400 \mathrm{mb}$ & 0.57 & 293 & 0.20 & 0.15 & 12 & 0.24 & 0.44 & 333 & 0.27 & 0.28 & 283 & 0.28 \\
\hline $8 \mathrm{~km}$ & & & & & & & 0.60 & 350 & 0.27 & & & \\
\hline $300 \mathrm{mb}$ & 0.61 & 313 & 0.28 & 0.37 & 332 & 0.26 & 0.51 & 346 & 0.33 & 0.42 & 357 & 0.33 \\
\hline $10 \mathrm{~km}$ & & & & & & & 0.70 & 2 & 0.34 & & & \\
\hline $200 \mathrm{mb}$ & 0.60 & 319 & 0.31 & 0.27 & 347 & 0.41 & 0.93 & 23 & 0.40 & 0.36 & 53 & 0.33 \\
\hline $12 \mathrm{~km}$ & & & & & & & 0.97 & 13 & 0.38 & & & \\
\hline $150 \mathrm{mb}$ & 0.33 & 19 & 0.23 & 0.39 & 359 & 0.32 & 0.79 & 23 & 0.24 & 0.55 & 20 & 0.31 \\
\hline $14 \mathrm{~km}$ & & & & & & & 0.67 & 13 & 0.30 & & & \\
\hline $16 \mathrm{~km}$ & & & & & & & 0.64 & 10 & 0.26 & & & \\
\hline $100 \mathrm{mb}$ & 0.53 & 6 & 0.22 & 0.19 & 25 & 0.34 & 0.67 & 10 & 0.26 & 0.48 & 326 & 0.26 \\
\hline $18 \mathrm{~km}$ & & & & & & & 0.47 & 8 & 0.24 & & & \\
\hline $20 \mathrm{~km}$ & & & & & & & 0.32 & 23 & 0.24 & & & \\
\hline
\end{tabular}

(b) Eastward wind component $(v)$

\begin{tabular}{|c|c|c|c|c|c|c|c|c|c|c|c|c|}
\hline \multirow[b]{2}{*}{ Height } & \multicolumn{3}{|c|}{ Shionomisaki } & \multicolumn{3}{|c|}{ Yonago } & \multicolumn{3}{|c|}{ Tateno } & \multicolumn{3}{|c|}{ Wajima } \\
\hline & AMP & PHA & PE & AMP & PHA & PE. & AMP & PHA & PE & AMP & PHA & $\mathrm{PE}$ \\
\hline $1000 \mathrm{mb}$ & 0.47 & 270 & 0.17 & 0.43 & 130 & 0.15 & 0.81 & 109 & 0.09 & 0.14 & 53 & 0.09 \\
\hline $850 \mathrm{mb}$ & 0.42 & 83 & 0.18 & 0.46 & 68 & 0.15 & 0.41 & 103 & 0.12 & 0.25 & 28 & 0.11 \\
\hline $2 \mathrm{~km}$ & & & & & & & 0.45 & 128 & 0.16 & & & \\
\hline $700 \mathrm{mb}$ & 0.29 & 182 & 0.20 & 0.18 & 143 & 0.11 & 0.49 & 146 & 0.12 & 0.25 & 135 & 0.16 \\
\hline $4 \mathrm{~km}$ & & & & & & & 0.52 & 161 & 0.16 & & & \\
\hline $500 \mathrm{mb}$ & 0.10 & 309 & 0.20 & 0.09 & 5 & 0.23 & 0.10 & 176 & 0.17 & 0.19 & 25 & 0.24 \\
\hline $6 \mathrm{~km}$ & & & & & & & 0.15 & 62 & 0.20 & & & \\
\hline $400 \mathrm{mb}$ & 0.50 & 325 & 0.23 & 0.49 & 296 & 0.30 & 0.07 & 324 & 0.29 & 0.16 & 177 & 0.25 \\
\hline $8 \mathrm{~km}$ & & & & & & & 0.39 & 87 & 0.37 & & & \\
\hline $300 \mathrm{mb}$ & 0.08 & 144 & 0.30 & 0.79 & 302 & 0.30 & 0.20 & 136 & 0.23 & 0.40 & 335 & 0.42 \\
\hline $10 \mathrm{~km}$ & & & & & & & 0.59 & 138 & 0.40 & & & \\
\hline $200 \mathrm{mb}$ & 0.39 & 176 & 0.33 & 0.76 & 322 & 0.33 & 0.30 & 226 & 0.33 & 0.34 & 271 & 0.35 \\
\hline $12 \mathrm{~km}$ & & & & & & & 0.49 & 207 & 0.33 & & & \\
\hline $150 \mathrm{mb}$ & 0.18 & 271 & 0.24 & 0.15 & 251 & 0.34 & 0.10 & 244 & 0.27 & 0.13 & 341 & 0.26 \\
\hline $14 \mathrm{~km}$ & & & & & & & 0.33 & 197 & 0.33 & & & \\
\hline $16 \mathrm{~km}$ & & & & & & & 1.09 & 2 & 0.39 & & & \\
\hline $100 \mathrm{mb}$ & 0.46 & 145 & 0.29 & 0.53 & 357 & 0.26 & 1.43 & 2 & 0.33 & 0.37 & 35 & 0.47 \\
\hline $18 \mathrm{~km}$ & & & & & & & 0.58 & 41 & 0.30 & & & \\
\hline $20 \mathrm{~km}$ & & & & & & & 0.77 & 60 & 0.38 & & & \\
\hline
\end{tabular}




\begin{tabular}{rrrrrrrrrrrrr}
\hline \multicolumn{3}{c}{ Sendai } & \multicolumn{4}{c}{ Akita } & \multicolumn{4}{c}{ Sapporo } & \multicolumn{4}{c}{ Wakkanai } \\
AMP & PHA & PE & AMP & PHA & PE & AMP & PHA & PE & AMP & PHA & PE \\
\hline 0.75 & 72 & 0.19 & 0.75 & 275 & 0.18 & 0.66 & 225 & 0.14 & 0.04 & 62 & 0.18 \\
0.25 & 140 & 0.23 & 0.42 & 98 & 0.16 & 0.59 & 67 & 0.11 & 0.69 & 36 & 0.18 \\
0.45 & 185 & 0.35 & 0.23 & 257 & 0.18 & 0.14 & 201 & 0.22 & 0.24 & 355 & 0.18 \\
0.47 & 250 & 0.24 & 0.43 & 267 & 0.21 & 0.35 & 295 & 0.23 & 0.27 & 265 & 0.23 \\
0.43 & 268 & 0.28 & 0.57 & 286 & 0.20 & 0.32 & 305 & 0.28 & 0.21 & 253 & 0.26 \\
0.40 & 226 & 0.49 & 0.64 & 326 & 0.37 & 0.29 & 293 & 0.37 & 0.06 & 349 & 0.39 \\
0.32 & 38 & 0.42 & 0.67 & 38 & 0.31 & 0.31 & 127 & 0.48 & 0.57 & 115 & 0.47 \\
0.89 & 8 & 0.53 & 0.38 & 122 & 0.27 & 0.33 & 175 & 0.52 & 0.39 & 17 & 0.51 \\
& & & & & & & & & & &
\end{tabular}

\begin{tabular}{|c|c|c|c|c|c|c|c|c|c|c|c|}
\hline \multicolumn{3}{|c|}{ Sendai } & \multicolumn{3}{|c|}{ Akita } & \multicolumn{3}{|c|}{ Sapporo } & \multicolumn{3}{|c|}{ Wakkanai } \\
\hline AMP & PHA & PE & AMP & PHA & $P E$ & AMP & PHA & $\mathrm{PE}$ & AMP & PHA & $\mathrm{PE}$ \\
\hline 0.44 & 29 & 0.19 & 1.54 & 239 & 0.14 & 0.34 & 248 & 0.13 & 0.17 & 237 & 0.14 \\
\hline 0.22 & 63 & 0.25 & 0.38 & 25 & 0.16 & 0.28 & 50 & 0.14 & 0.14 & 30 & 0.14 \\
\hline 0.35 & 176 & 0.25 & 0.23 & 21 & 0.15 & 0.16 & 64 & 0.17 & 0.26 & 140 & 0.15 \\
\hline 0.58 & 162 & 0.20 & 0.14 & 167 & 0.20 & 0.15 & 39 & 0.20 & 0.24 & 171 & 0.25 \\
\hline 0.23 & 152 & 0.19 & 0.13 & 170 & 0.24 & 0.27 & 303 & 0.35 & 0.05 & 102 & 0.30 \\
\hline 0.82 & 188 & 0.33 & 0.09 & 301 & 0.34 & 0.59 & 271 & 0.36 & 0.92 & 234 & 0.43 \\
\hline 0.42 & 73 & 0.36 & 0.54 & 25 & 0.40 & 0.66 & 338 & 0.69 & 0.70 & 226 & 0.39 \\
\hline 0.69 & 117 & 0.88 & 0.13 & 179 & 0.25 & 0.70 & 36 & 0.90 & 0.61 & 299 & 0.47 \\
\hline 0.18 & 85 & 0.30 & 0.36 & 114 & 0.31 & 0.46 & 172 & 0.39 & 0.23 & 93 & 0.42 \\
\hline
\end{tabular}




\section{References}

Carlson, Jr., G. C., and S. Hastenrath, 1970: Diurnal variation of wind, pressure, and temperature in the troposphere and stratosphere over Eniwetok. Mon. Wea. Rev., 98, 408-416.

Chapman, S., and R.S. Lindzen, 1970: Atmospheric Tides. D. Reidel Pub. Co., Dordrecht-Holland, 200 pp. (see pp. 63-65).

Harris, M. F., 1959: Diurnal and semidiurnal variations of wind, pressure, and temperature in the troposphere at Washington, D.C. J. Geophys. Res., 64, 983-995.

, F. G. Finger, and S. Teweles, 1962: Diurnal variations of wind, pressure, and temperature in the troposphere and stratosphere over the Azores. J. Atmos. Sci., 19, 136-149.

and thermal influences in the solar semidiurnal tide. Mon. Wea. Rev., 94, 427-447.

Hering, W. S., and T. R. Borden, Jr., 1962: Diurnal variations in the summer wind field over the central United States. J. Atmos. Sci., 19, 8186.

Japan Meteorological Agency, 1956-1959: Geophysical Review. Nos. 677 (Jan. 1956)-688 (Dec. 1956), and 701 (Jan. 1958)-712 (Dec. 1958), Japan Meteorological Agency, Tokyo (in Japanese).
1956-1959: Aerological Data of Japan. vols. Jan. 1956-Dec. 1956, and Jan. 1958-Dec. 1958, Japan Meteorological Agency, Tokyo.

Johnson, D. H., 1955: Tidal oscillations of the lower stratosphere. Quart. J. Roy. Meteor. Soc., 81, $1-8$.

Kato, S., 1966: Diurnal atmospheric oscillation, 1. Eigenvalues and Hough functions. J. Geophys. Res., 71, 3201-3209.

Lindzen, R.S., 1966: On the theory of the diurnal tide. Mon. Wea. Rev., 94, 295-301.

1967: Thermally driven diurnal tide in the atmosphere. Quart. J. Roy. Meteor. Soc., 93, $18-42$.

Reed, R. J., M. J. Oard, and M. Sieminski, 1969: A comparison of observed and theoretical diurnal tidal motions between 30 and 60 kilometers. Mon. Wea. Rev., 97, 456-459.

Siebert, M., 1961: Atmospheric tides. In Advances in Geophysics. \%, Academic Press, New York, pp. 105-182.

Wallace, J. M., and F. R. Hartranft, 1969: Diurnal wind variations, surface to 30 kilometers. Mon. Wea. Rev., 97, 446-455.

- and R.F. Tadd, 1974: Some further results concerning the vertical structure of atmospheric tidal motions within the lowest 30 kilometers. Mon. Wea. Rev., 102, 795-803.

\title{
日本上空の対流圏および下部成層圈に於ける風の一日周期振動
}

\author{
吉田 淳* ・廣田勇 \\ 京都大学理学部地球物理学教室
}

1956年と1958 年の気球観測データを用いて，日本上空 $1000 \mathrm{mb}-100 \mathrm{mb}$ の間の 9 高度に於ける風の一日周期振動 (大気潮汐) を求めた。対流圈拉よび下部成層圈では, この一日周期の大気潮汐振動は地形に強く影響されることが この解析でも確かめられた。日本のような中緯度の地点でははっきりとした振動の季節変化は検出できないが, 地点 による不規則さは冬の方がより上層まで現われている。これは冬の大気の性質（iet 気流など）によるものと考兄ら れる。

更に，中緯度の異なった地形環境にある気球観測地点での解析結果を他の論文から引用し，今回の解析と比較した 結果では, 海岸・大陸内部・大洋上空での一日周期振動に興味深い違いが発見された。Laplace の潮汐方程式の解か ら予想される propagating modes と呼ばれ, 励起源から上下に遠くまで振動が伝わるような波は観測では海岸上 空で強く, trapped modes と呼ばれ, 励起源からあまり遠くまで振動が伝わらないよらな波は, 大陸内部上空で比 較的強いことがわかった。

対流圏・下部成層圏に於ける, 観測事実と Lindzen $(1966,1967)$ の理論的モデルとの食い違いは, 地形の影響 （主に海陸分布・地表温度の日变化・大山哌など）や平均場などを考慮することによって部分的に補正することがで きるであろう。

\footnotetext{
* 現在所属 : 米国オクラホマ大学気象学教室
} 